\title{
The effectiveness of hepa filtered rooms plus fluconazol prophylaxis for preventation of invasive fungal diseases in allogenic stem cell transplant patients
}

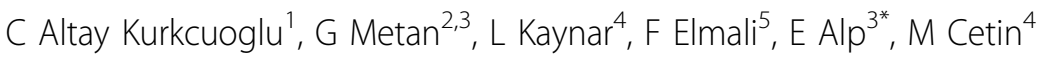 \\ From 3rd International Conference on Prevention and Infection Control (ICPIC 2015) \\ Geneva, Switzerland. 16-19 June 2015
}

\section{Introduction}

In our hematopoieteic stem cell transplantation (HSCT) center, preventation of invasive fungal diseases (IFDs) for the patients who did not experience IFDs previously is based on performing allogeneic SCT in rooms with "High efficiency particulate air" (HEPA) filters and administration of fluconazole prophylaxis.

\section{Objectives}

We aimed to evaluate our prophylaxis policy to ensure if preventive measures are working.

\section{Methods}

Erciyes University Hospital is a 1300-bed tertiary centre with a 38-bed HSCT center. We retrospectively reviewed records of 146 ASCT episodes between January 2012 and December 2014 to detect the patients with IFDs before engraftment. Patients who experince IFDs before ASCT were excluded from the study. As fluconazole has no activity against Aspergillus spp, an early diagnostic policy for invasive aspergillosis (IA) was guided by twice weekly Aspergillus Galactomannan antigen detection from the day of neutropenia until engraftment and radiological interventions when clinically required. The European Organization for Research and Treatment of Cancer and the Mycoses Study Group criteria were used to categorize the patients as having proven, probable, or possible IA. IA is accepted as nosocomial if patient was hospitalized more than seven days and no history of previous IFDs in the last six months.

${ }^{3}$ Infectious Diseases and Clinical Microbiology, Erciyes University Faculty of Medicine, Kayseri, Turkey

Full list of author information is available at the end of the article

\section{Results}

The 105 out of 146 ASCT episodes were from matched related donor, 10 were from matched unrelated donor, and 31 were haploidentical ASCT. Possible IA was diagnosed in 10 patients, probable IA was diagnosed in 3 patients, proven IA in 1 patient, and fungemia was detected in 4 patients. Candida mucositis was diagnosed in 7 patients. The crude mortality rate in three months after ASCT was 10.4\% (4 patients with IFDs vs 11 patients without IFDs) in 144 ASCT patients who were followed by our center.

\section{Conclusion}

ASCT in rooms with HEPA filters with positive pressure, combined with fluconazole prophylaxis prevented IFDs in $82.8 \%$ of the 146 ASCT episodes in pre-engraftment period.

\section{Disclosure of interest}

C. Altay Kurkcuoglu: None declared, G. Metan Grant/ Research support from: Associates of Cape Cod, Conflict with: Member of Advisory board for Pifizer, Gilead, Astellas, L. Kaynar: None declared, F. Elmali: None declared, E. Alp: None declared, M. Cetin: None declared.

\footnotetext{
Authors' details

Infection Control Committee, Erciyes University Hospital, Kayseri, Turkey. ${ }^{2}$ Infectious Diseases and Clinical Microbiology, Hacettepe University Faculty of Medicine, Ankara, Turkey. ${ }^{3}$ Infectious Diseases and Clinical Microbiology, Erciyes University Faculty of Medicine, Kayseri, Turkey. ${ }^{4}$ Hematology, Erciyes University Faculty of Medicine, Kayseri, Turkey. ${ }^{5}$ Biostatisitics, Erciyes University Faculty of Medicine, Kayseri, Turkey.
} 
doi:10.1186/2047-2994-4-S1-P274

Cite this article as: Kurkcuoglu et al:: The effectiveness of hepa filtered rooms plus fluconazol prophylaxis for preventation of invasive fungal diseases in allogenic stem cell transplant patients. Antimicrobial Resistance and Infection Control 2015 4(Suppl 1):P274.

Submit your next manuscript to BioMed Central and take full advantage of:

- Convenient online submission

- Thorough peer review

- No space constraints or color figure charges

- Immediate publication on acceptance

- Inclusion in PubMed, CAS, Scopus and Google Scholar

- Research which is freely available for redistribution

Submit your manuscript at www.biomedcentral.com/submit
C Biomed Central 